POLICY DISCUSSION PAPERS

Globalization and Imbalances in Historical Perspective

By Michael D. Bordo 


\section{Globalization and Imbalances in Historical Perspective}

By Michael D. Bordo

Global imbalances associated with the U.S. current account deficit have given rise to speculation about the nature of the impending adjustment: Will it be smooth and gradual, or will it be sudden and costly? This Policy Discussion Paper summarizes the two views and then considers three historical periods with similar pressures - an earlier era of globalization from 1870 to 1914, the interwar gold standard, and Bretton Woods. A comparison of the periods and their outcomes suggests current global imbalances might resolve themselves quietly. This paper was originally presented to the Cleveland Committee on Foreign Relations at the Federal Reserve Bank of Cleveland on March 9, 2005.
Michael D. Bordo is a professor of economics Rutgers University and a research associate at the National Bureau of Economic Research.
Materials may be reprinted, provided that the source is credited. Please send copies of reprinted materials to the editor.

Policy Discussion Papers are published by the Research Department of the Federal Reserve Bank of Cleveland.To receive copies or to be placed on the mailing list, e-mail your request to 4dsubscriptions@clev.frb.org or fax it to 216-579-3050. Please send your questions comments, and suggestions to us at editor@clev.frb.org.

Policy Discussion Papers are available on the Cleveland Fed's site on the World Wide Web: www.clevelandfed.org/Research.

Views stated in Policy Discussion Papers are those of the authors and not necessarily those of the Federal Reserve Bank of Cleveland or of the Board of Governors of the Federal Reserve System. 


\section{The Current Situation}

\section{The Gloomy View}

Recent concerns over global imbalances associated with the U.S. current-account-deficit-to-GDP ratio in excess of 5 percent (see figure 1) and U.S. net foreign liabilities of $\$ 2.7$ trillion or 25 percent of GDP (see figure 2) have raised fears of a drastic readjustment involving a massive depreciation of the dollar (as large as 90 percent in some scenarios [Blanchard et al. 2005]). It has already fallen about 30 percent in nominal trade-weighted terms against our major trading partners (see figure 3) - with attendant potentially serious effects on the U.S. and global economies (see, for example, Obstfeld and Rogoff 2004).The adjustment would involve reallocation of consumption and production in the United States from nontraded to traded goods and a possible rise in inflation, which would lead to greater tightening of monetary policy, which would, in turn, induce a recession. The decline in income would reduce both the demand for imports and domestic consumption and encourage domestic saving, simultaneously improving the two faces of imbalance-the current account and the savings investment gap.

At the same time, the adjustment would have opposite effects in Europe and Japan, areas with current account surpluses and excess savings (see figures 4 and 5). To the extent that European nominal rigidities prevent it from adjusting to the decline in demand for its exports to the United States, its real economy could suffer. China, with its currency pegged to the dollar, would not have to adjust much and would gain a competitive advantage in the U.S. market-especially against Europe.

In addition, it is argued that, to the extent that the imbalances have been financed by foreign-especially East Asian - central banks' accumulation of U.S. treasury bills (up to 65 percent of their international reserves), some point will be reached where these central banks will dump their depreciating dollar assets and shift their portfolios towards the euro, thereby aggravating the situation.

The current situation is often attributed to the IT boom of the 1990s, which induced a massive private capital inflow to U.S. equity markets. The bursting of the tech boom (bubble) in 2000, followed by $9 / 11$, a U.S. recession, and the wars in Afghanistan and Iraq, led to a shift of the U.S. budget deficit from surplus to a deficit of close to 4 percent of GDP.This twin deficit problem is viewed as a key determinant of the deteriorating situation (Frankel 2004).

\section{The Benign View}

An alternate view does not regard the outlook in such bleak terms. It posits that adjustment will be smooth, protracted, and benign, very much like what happened in the late 1980s, when the U.S. current account deficit recorded a peak of about 4 percent of GDP.This view (see, for example, Greenspan 2003) stresses the underlying force of financial globalization-a burgeoning phenomenon since the 1970s and one which has encouraged residents of open economies to increase their holdings of foreign assets as a way to diversify portfolios and smooth out shocks to consumption.

Global assets and liabilities have mushroomed in the past three decades, especially in the 1990s (Lane and Milesi-Ferreti 2005). Globalization and a decline in home bias-a tendency of domestic investors to prefer domestic assets in their portfolios-have deepened and broadened financial markets around the world and, above all, in the United States, which has seen a disproportionate growth in the demand for its assets because it offers a higher real rate of return based on the economy's long-run good performance. 


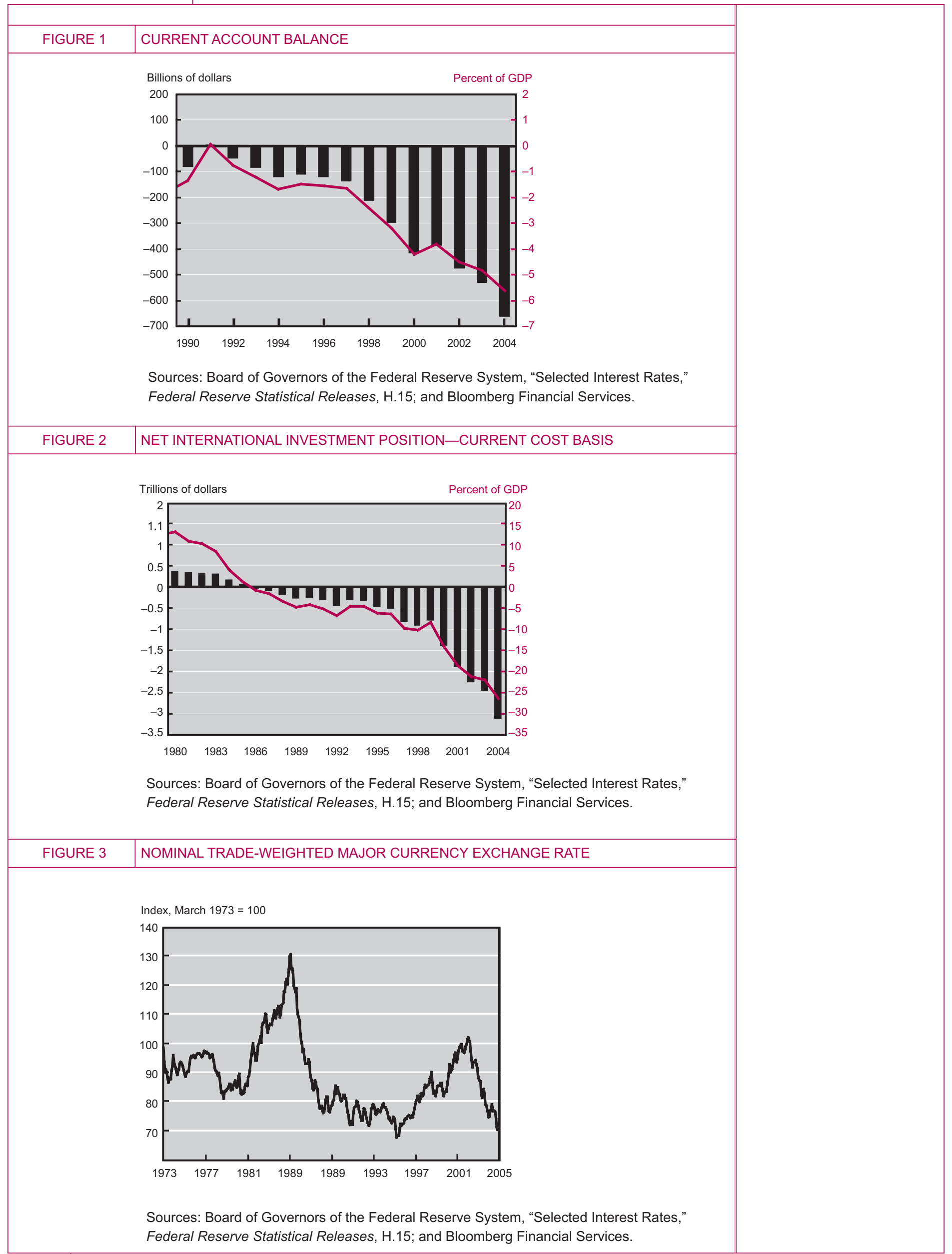


Thus in this view, the current account deficit and the rise in U.S. net foreign liabilities reflect the demand for U.S. instruments by foreigners. Adjustment, to the extent it needs occur, will be benign because the underlying long-run positive fundamentals will continue, and for two additional reasons: valuation and a reduced pass-through. Valuation effects refer to the fact that, to the extent dollar depreciation is unexpected, it will reduce the value of U.S. foreign liabilities (Gourinchas and Rey 2004). A reduced pass-through is suggested by recent empirical evidence, which shows that only a very small fraction of dollar depreciation passes through to higher inflation (Greenspan 2005).

\section{Globalizing Capital Flows and the Adjustment Mechanism:} A Benign Outcome a Century Ago

A different and perhaps enlightening perspective on the issue is to delve into economic history for earlier episodes of global imbalances, which may have some resonance for today and which may tell us what is in store for the future. An important precedent for the benign outcome view is the previous era of financial globalization, which took place from 1870 to 1914 . It was characterized by a rapid

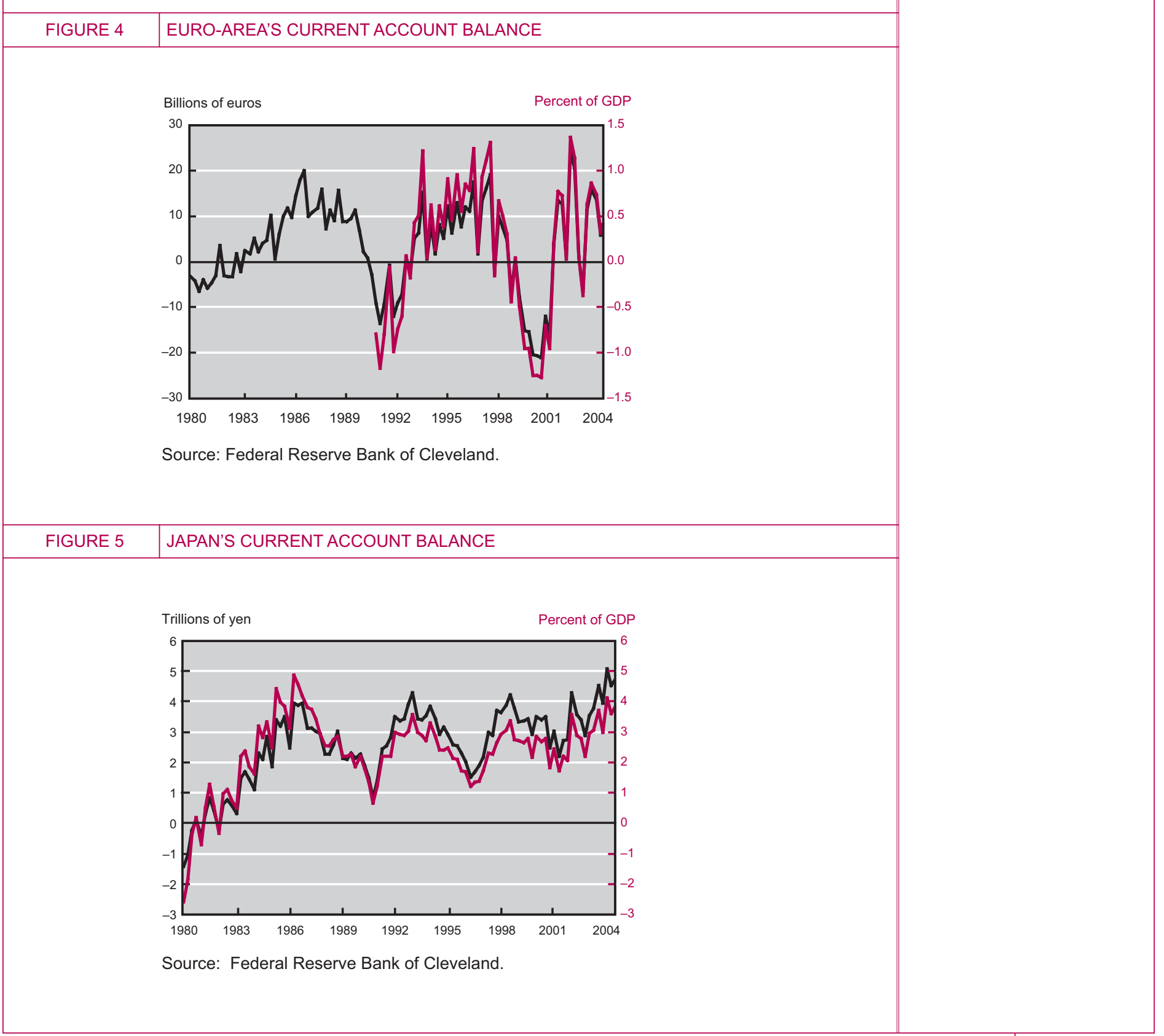


global buildup of external assets and liabilities and also of long-standing current account imbalances comparable to today's experience.

The 50 years before World War I saw massive net private flows of capital from the core countries of Western Europe to the countries of recent settlement overseas (mainly the rapidly developing Americas and Australasia), financing railroads and other infrastructure as well as budget deficits (especially in the form of bonds but also in the form of foreign direct investment). At the peak, the associated current account surpluses in Britain reached 9 percent of GDP and were almost as big in France, Germany, and the Netherlands (See figure 6). For the principal capital importers in the late nineteenth century (Argentina, Australia, and Canada), current account deficits exceeded 5 percent of GDP on average. Earlier in the century, the United States experienced similar flows but by the century's end it began to run current account surpluses.

In addition, data on ratios of stocks of foreign assets and liabilities to GDP for selected countries and regions, compiled in Obstfeld and Taylor (2003), presents a picture of a u-shaped pattern. At its pre-1914 peak, the share of foreign assets to world GDP was approximately 20 percent. It declined from that level to a low of 5 percent in 1945, with the prewar level only being reached by 1985 .After that point, it rose to 57 percent by 1995.A similar picture emerges from the ratio of liabilities to overall GDP.

The British held the lion's share of overseas investments in 1914-50 percent-followed by France at 22 percent, Germany at 17 percent, the United States at 6.5 percent, and the Netherlands at 3 percent. By comparison, the United States held 25 percent of global assets in 1995. These funds in turn represented up to one-half of the capital stock of one of the major debtors (Argentina) and close to one-fifth for Australia and Canada.

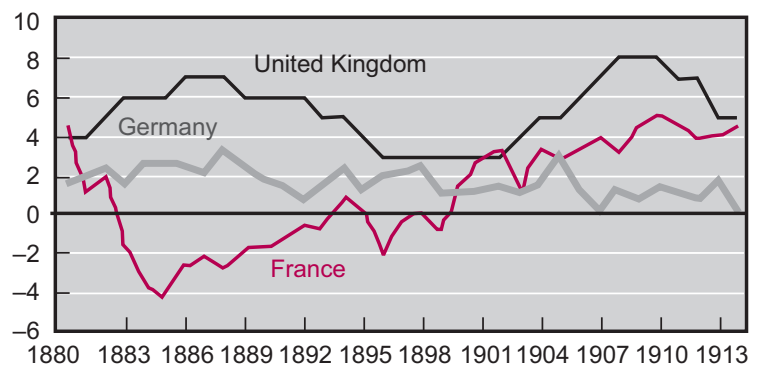

DEFICIT COUNTRIES (DURING GOLD STANDARD)

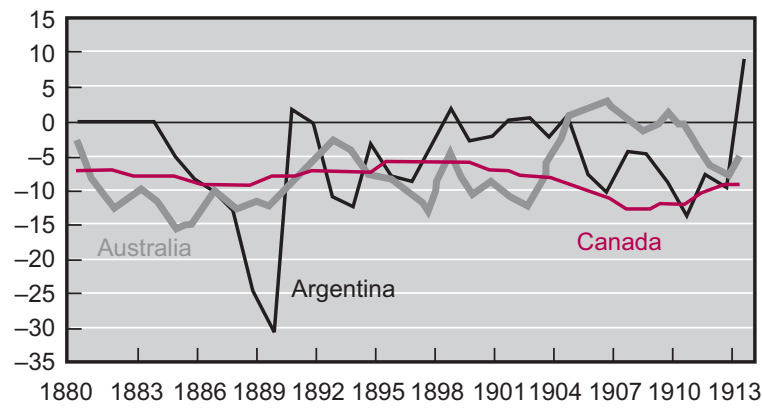


A striking feature of the pre-1914 data is the persistence of imbalances in the current account. Bordo, Eichengreen, and Kim (1998), using the coefficients of an AR(1) regression as well as an augmented Dickey-Fuller (ADF) test, find evidence of significantly greater persistence in both the deficits of the principal capital recipients and the capital exporters compared to the recent experience. Similar evidence is seen in variance ratios calculated by the authors.

Finally, the mechanism of adjustment to the massive capital transfer worked very smoothly. It occurred through the price-specie-flow mechanism of the classical gold standard (Bordo 1984). The transfer of long-term capital from Europe to the New World to finance railroads and other infrastructure was also accompanied by gold flows as the demand, for example, for U.S. railroad bonds by British investors led to a demand for dollars, pushing the dollar to the gold-import point. The gold inflows in turn tended to raise the price of U.S. exports relative to imports, that is, to improve the terms of trade, (as well as raise the ratio of the prices of traded and nontraded goods). It also allowed the United States to import more goods than otherwise-much of these imports consisting of capital goods such as rails from Britain.As relative prices adjusted, the gold flows would tend to be reversed, closing the imbalance. Moreover, short-term capital movements speeded up adjustment as gold flows into the United States reduced interest rates relative to Britain.

Many believe that the smooth adjustment to the capital transfers of the pre-1914 era reflects the fact that the world was on the gold standard, which provided a stable and credible nominal anchor. The gold standard also served as a signal of fiscal rectitude ("a good housekeeping seal of approval"), which assured investors that their debt would be repaid and serviced (Bordo and Rockoff 1996).Also, many of the capital recipients were part of the British Empire, which established institutions and safeguards that virtually eliminated country risk. For example, colonial (Dominion) governments were given debt trustee status in the United Kingdom (which meant they had a de facto British government guarantee).

However, the adjustment mechanism in the earlier era of globalization was not always benign. Although current account imbalances were more long-lived in the pre-1914 era than in the recent period, they were punctuated in some countries by severe reversals, especially in the crisis-ridden 1890s (Bordo and Eichengreen 1999). The classic financial crisis of the era was the Barings crisis of 1890, which began with a debt default in Argentina and spread like wildfire to the rest of the emerging world. Lenders in London and Paris cut off capital flows to emerging countries like Brazil (Triner and Wandschneider 2005) with fundamentals similar to those of Argentina, while other countries deemed sound, such as Canada, were only marginally affected (Bordo and Murshid 2000). Thus the emerging-market crisis problem had historical precedents. Most of the countries affected, those of Latin America and Southern Europe, lacked the fundamentals, specifically, institutions and policies, associated with the more successful recipients.

Although the imbalances of the previous age of globalization has considerable resonance for today-especially the fact that both eras were characterized by stable meta regimes (the gold standard then and the adherence by many countries today to credible domestic nominal anchors, such as inflation targeting and norms for fiscal balance), there are also considerable differences. First, under the gold standard, countries of new settlement-the emerging markets of the time-ran current account deficits, while the major European economies ran surpluses. In the current era, there is no such delineation: some major economies run persistent deficits, some persistent surpluses, and the same is true of emerging-market economies. 
Second, before 1914, gross capital flows were much smaller than they are today, and gross asset and liability positions were very close to net positions, in contrast to today, where most major industrial countries are either major creditors or debtors. The earlier pattern reflects the prevalence of longterm investment by the core countries in the countries of new settlement. The substantial growth of two-way flows between advanced countries since 1980 has been associated with both international financial diversification and intertemporal consumption smoothing.

Third, the adjustment mechanism is different. The historical record shows that adjustment to the significant and persistent external imbalances in the pre-1914 era occurred largely through the Humean price-specie-flow mechanism of the classical gold standard. In contrast, the global economy is now on a managed floating exchange rate regime, and instead of gold flows, the brunt of the external adjustment occurs through changes in the exchange rate and international reserves, along with relative price movements, short-term capital flows, and valuation effects (Obstfeld 2004).

Finally, in the pre-1914 era, Great Britain was the dominant country. Its currency, the pound, served as the international medium of exchange and as a key reserve asset. Great Britain ran considerable current account surpluses throughout the period. By contrast, the United States is the dominant economy today and the dollar is the key currency, but the United States has been running persistent current account deficits.

\section{Further Lessons from History: Some Bad Outcomes}

History also gives two other, not-so-rosy scenarios of global imbalances and how they were adjusted to: the interwar gold exchange standard and the Bretton Woods system.

\section{The Interwar Adjustment}

World War I ended the classical gold standard as all of the belligerents except the U.S. abandoned gold convertibility. Private capital flows also ceased.After the war, by 1926, the major countries returned to a variant of the gold standard, the gold exchange standard in which members held most of their international reserves in dollars, sterling, and francs, and the U.S., Great Britain, and France held gold.

But the interwar gold exchange standard had serious flaws, which prevented smooth adjustments to the imbalances that built up (Meltzer 2003, Eichengreen 1992). The key problem was that the major countries returned to gold at misaligned real exchange rates.All the belligerents had serious inflations during the war, and the restoration of the original gold parities involved deflation and recession.As it turned out, Britain restored parity at $\$ 4.86$ with an overvalued real exchange rate while France and Germany each greatly devalued their currencies and restored parities at undervalued real levels (see figure 7). Although the United States never left the gold standard during the war, U.S. prices did not return to the prewar level, so that the country's postwar real exchange rate was also undervalued. This misalignment meant that the United States, France, and Germany tended to run current account surpluses while Britain, its empire, and the countries economically linked to it ran deficits. Under the gold standard, this meant that gold tended to flow toward the surplus countries.Also, under the gold standard rules, both creditors and debtors were supposed to adjust to the imbalances-creditors by allowing domestic price levels to rise, debtors by deflation. As it turned out, both the United States and France continuously sterilized their gold flows and prevented adjustment (Meltzer 2003). As a consequence, they imposed deflationary pressure on Britain and on the rest of the world.

Another important difference between the classical and interwar gold standards that impaired the adjustment mechanism in the latter was the lack of credibility in the member countries' adherence to 
gold convertibility. Unlike in the earlier period, markets had limited confidence that countries would always put external balance considerations before domestic policy concerns (Eichengreen 1992). This meant that short-term capital movements could be destabilizing. In the end, the system collapsed after 1929 in the face of the Great Depression. Speculative attacks against countries that used expansionary monetary policy to alleviate banking panics and to stabilize the real economy forced country after country to abandon the gold standard (Eichengreen 1992). This was not the case for the United States however; it had adequate gold reserves to withstand speculative attacks (Bordo, Choudhri, and Schwartz 2002). The United States left the gold standard in 1933 as part of Roosevelt's policy package to reflate the U.S. economy (Meltzer 2003).

\section{The Bretton Woods Adjustment}

Under the post-World War II Bretton Woods system, a distant variant of the gold standard, the United States was the dominant country, with the largest gold reserves (Bordo 1993). Under Bretton Woods' rules, the United States had to peg the dollar to gold at $\$ 35.00$ per ounce, and the rest of the world pegged to the dollar.The rest of the world used dollars as international reserves, and the dollar served as the international medium of exchange. The United States was also supposed to follow stable monetary and fiscal policies.

During the period 1959-1971, when the system fully operated (most members had current account convertibility), the United States ran persistent current account and trade surpluses and also engaged in considerable foreign investment. The overall balance of payments was generally in deficit and the rest of the world absorbed dollar claims (see figure 8). At the same time it is argued that the principal continental European countries and Japan kept their real exchange rates deliberately undervalued in order to foster export-driven growth in their economies (Dooley et al. 2002). This policy meant that they kept accumulating dollars, which they sterilized, just as the United States and France had during the interwar period. It has been argued that during this period, the United States acted as financial intermediary to the rest of the world, importing short-term capital (dollar claims) and exporting long-term capital (McKinnon 1969).

From 1961 to 1967, Europe and Japan's holding of dollar claims convertible into gold kept increasing relative to gold holdings in the United States, suggesting the possibility of a run on the dollar (see figure 9).

\section{\begin{tabular}{l|l} 
FIGURE 7 & REAL EXCHANGE RATES (CPI)
\end{tabular}}

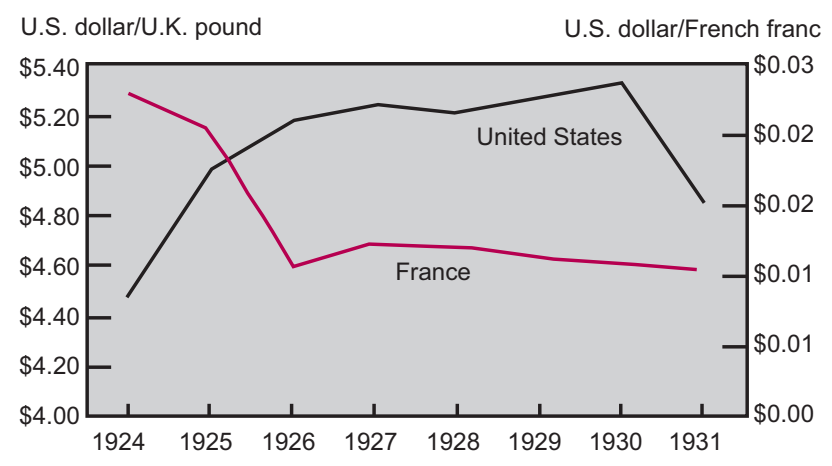

Note: The dollar-pound parity in 1925 was $\$ 4.86$, and the dollar-franc parity in 1927 was $\$ 0.0392$.

Source: Bordo et al. 2001. 
McKinnon (1969), Meltzer (1991), and others have argued that the system could have continued for an extended period as a de facto dollar standard. However, two factors led to the collapse of the Bretton Woods system. First, the French resented the United States' "exorbitant privilege” of not having to adjust to its payments imbalances because it was the principal reserve country.They wanted a return to a pure gold standard, and to facilitate this outcome, they converted their outstanding dollar claims into gold. Second, the United States began to follow inflationary monetary and fiscal policies beginning in 1965-to finance the Vietnam War and the Great Society.

The expansionary policies increased both the U.S. payments deficit and European central bank reserves, as the United States exported its inflation abroad.As a consequence, the Europeans began converting their dollar claims into gold, threatening U.S. gold reserves. The system collapsed when Richard Nixon closed the gold window in August 1971.

It has been argued that a reincarnated Bretton Woods system exists today. China, possibly India, and other countries are seen as deliberately running an undervalued peg against the dollar to encourage export-driven growth the way Europe and Japan did 40 years ago (Dooley et al. 2002). The central banks of these countries willingly accumulate dollar assets consequent upon their current
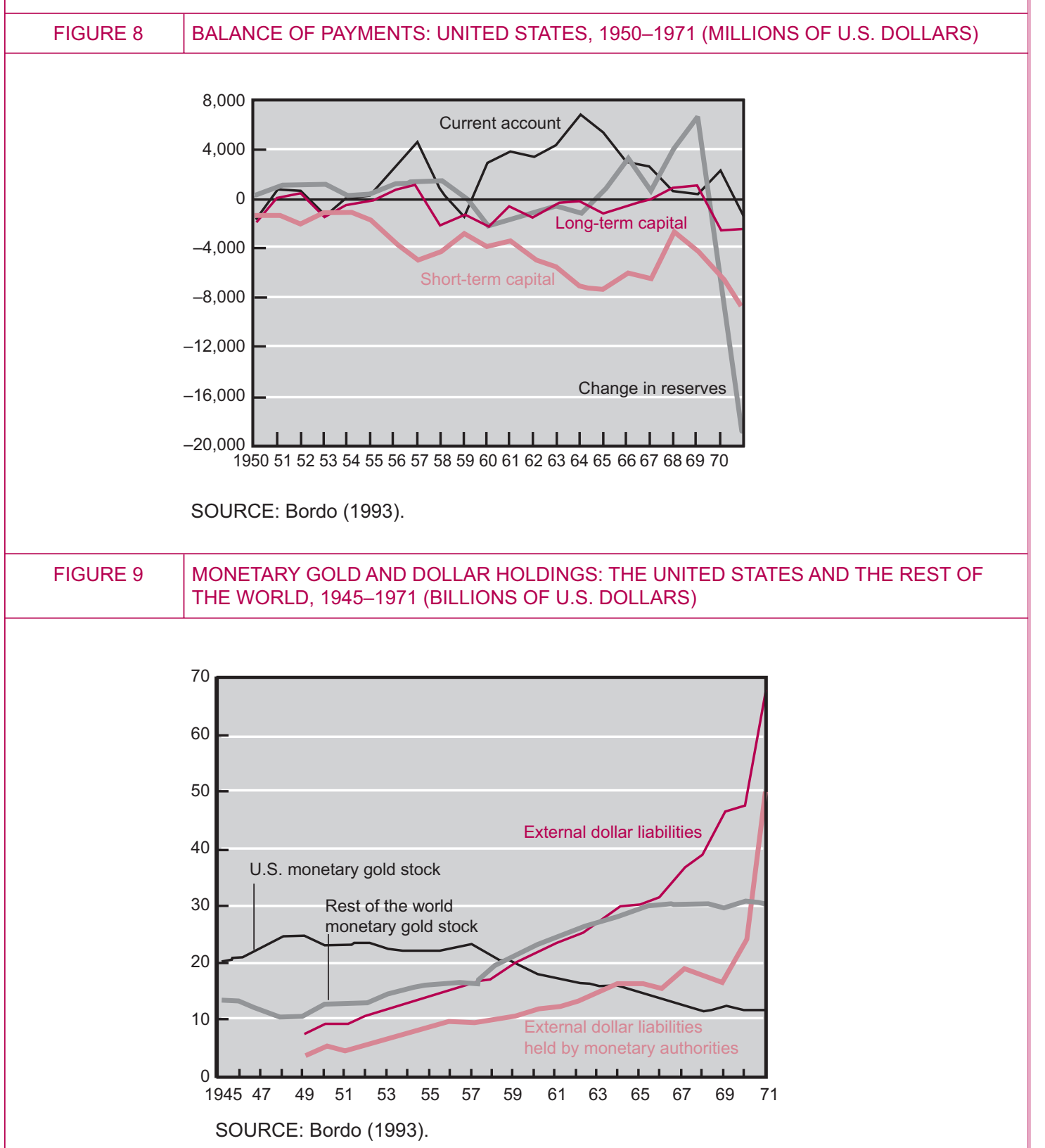
account surpluses. Dooley et al. argue that such a relationship could persist for as long as a decade to allow China to absorb its 200 million surplus agricultural workers into the manufacturing sector.

Others argue that the reincarnated system will not last for 10 years but will collapse much sooner because, unlike the Europeans in the 1960s, Asian central banks do not have a stable cartel (Eichengreen 2004). Furthermore, in the Bretton Woods era, there were no good substitutes for the dollar as the world's reserve asset (the pound was a reserve asset, but it was weak), but today we have the euro. They predict the system will collapse quickly.

\section{What Will Happen?}

We have illustrated three historical episodes of external imbalances and their adjustment.Two ended in a collapse.The third worked remarkably well. Which episode is more relevant to today's environment? My bet is a benign outcome, like that of the prewar gold standard era. In today's world, the underlying fundamental of globalization and the basic strength of the U.S. economy-which will continue to underpin the dollar as a reserve asset-suggest that adjustment to the present set of imbalances will be gradual, and, when all is said and done, the experience will be viewed as similar to what happened in the late 1980s.

\section{References}

Blanchard, Olivier, Francesco Giavazzi, and Filipa Sa."The U.S. Current Account and the Dollar." National Bureau of Economic Research Working Paper, no. 11137, February 2005.

Bordo, Michael D., Ehsan Choudhri, and Anna J. Schwartz. "Was Expansionary Monetary Policy Feasible During the Great Contraction?" Explorations in Economic History, January 2002.

Bordo, Michael D., Barry Eichengreen, Daniela Klingebiel, and Maria Soledad Martinez-Peria. "Is the Crisis Problem Growing More Severe?" Economic Policy, vol. 32 (April 2001), pp. 53-82.

Bordo, Michael D. , and Antu Murshid. 2001, "Are Financial Crises Becoming More Contagious: What is the Historical Evidence on Contagion?" In Stijn Claessens and Kristin J. Forbes (eds.), International Financial Contagion, Boston: Kluwer, 2001, pp. 367-403.

Bordo, Michael D., and Barry Eichengreen. "Is Our Current International Economic Environment Unusually Crisis Prone?" In David Gruen and Luke Gower (eds.), Capital Flows and the International Financial System, Sydney: Reserve Bank of Australia, 1999, pp.18-75.

Bordo, Michael D., Barry Eichengreen, and Jong Woo Kim. "Was There Really an Earlier Period of International Financial Integration Compared to Today?" In The Implications of Globalization of world Financial Markets. Seoul:Bank of Korea, 1998.

Bordo, Michael D., and Hugh Rockoff. "The Gold Standard as a Good-Housekeeping Seal of Approval." Journal of Economic History, vol. 56 (1996), pp.389-428.

Bordo, Michael D. "The Bretton Woods International Monetary System: A Historical Overview." In Michael D. Bordo and Barry Eichengreen (eds.), A Retrospective on the Bretton Woods System, Chicago: University of Chicago Press, 1993. 
Bordo, Michael D. "The Gold Standard: The Traditional Approach." In Michael D. Bordo and Anna J. Schwartz (eds.) A Retrospective on the Classical Gold Standard, 1821-1931. Chicago: University of Chicago Press, 1984.

Dooley, Michael P., David Folkerts-Landau, and Peter Garber. "An Essay on the Revived Bretton Woods System.” National Bureau of Economic Research Working Paper, no. 9971 (September 2002).

Eichengreen, Barry. "Global Imbalances and the Lessons of Bretton Woods." National Bureau of Economic Research Working Paper, no. 10497 (2004).

Eichengreen, Barry. Golden Fetters. New York Oxford University Press, 1992.

Frankel, Jeffrey. "Twin Deficits and Twin Decades," unpublished manuscript, Harvard University, May 2004.

Greenspan, Alan. "Current Accounts," remarks given at the Advancing Enterprise 2005 conference, London, England, February 4, 2005.

Greenspan, Alan. Remarks on the 21st Annual Monetary Conference, cosponsored by the Cato Institute and the Economist. Washington, D.C., November 20, 2003.

Lane, Philip R., and Gian Maria Milesi-Ferretti. "Financial Globalization and Exchange Rates," International Monetary Fund Working Paper, no. 05/03 (2005).

Mckinnon, Ronald. "Private and Official Money:The Case for the Dollar." In Princeton Essays in International Economics. Princeton University, International Finance Section, 1969.

Meltzer, Allan. A History of the Federal Reserve, vol. I, 1913-1951. Chicago: University of Chicago Press, 2003.

Meltzer,Allan. “U.S. Policy in the Bretton Woods Era." Federal Reserve Bank of St. Louis, Review, vol. 73 (May/June 1991), pp. 54-83.

Obstfeld, Maurice. "External Adjustment," National Bureau of Economic Research Working Paper, no. 10843 (October 2004).

Obstfeld, Maurice, and Kenneth Rogoff. "The Unsustainable Current Account Position Revisited, National Bureau of Economic Research Working Paper, no. 10869 (October 2004).

Obstfeld, Maurice, and Alan Taylor. Global Capital Markets: Integration, Crisis and Growth. Cambridge: Cambridge University Press, 2004.

Gourinchas, Pierre-Olivier, and Helene Rey. "International Financial Adjustment" National Bureau of Economic Research Working Paper, no. 11155 (2005).

Triner, Gail, and Kirsten Wandschneider. "International Capital and the Brazilian Encilhamento, 1889-1892: An Early Example of Contagion among Emerging Markets." Financial History Review (2005). 


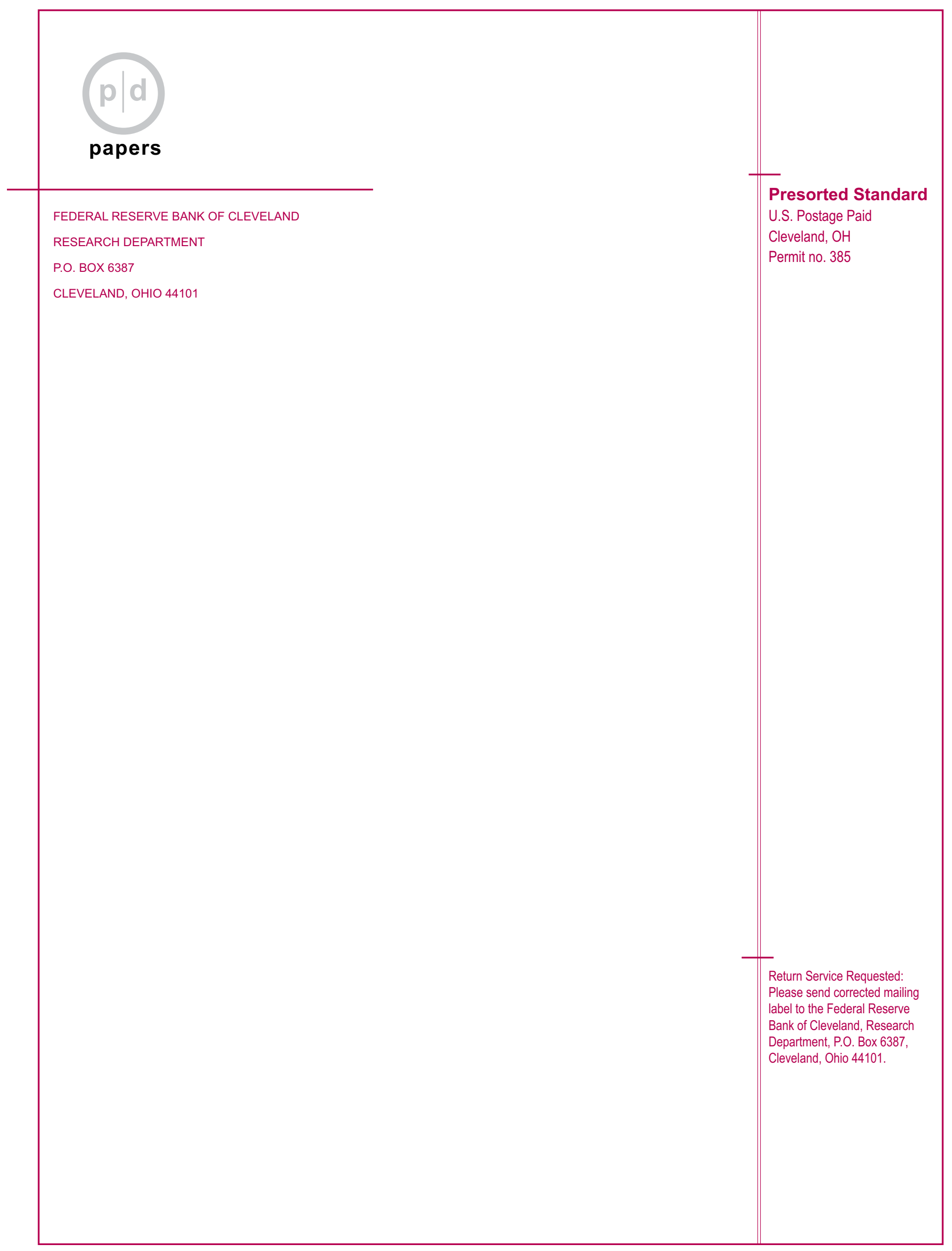

